\title{
Slope vulnerability, mass wasting and hydrological hazards in Himalaya: a case study of Alaknanda Basin, Uttarakhand
}

\author{
Bindhy W. Pandey, Abhay S. Prasad \\ Department of Geography, Delhi School of Economics, University of Delhi, Delhi-110007, India \\ EMAIL: BWPDSEGE0@GMAIL.COM, ABHAYDSE@HOTMAIL.cOM
}

\begin{abstract}
Himalayan geosystem is highly vulnerable and susceptible to various kinds of Geo-hydrological vulnerability. Anthropogenic activities are continuously disturbing the natural system and its impact on the hydrological behavior of river. The important factor causing a flood and also accelerate several hydrological hazards during monsoon periods are heavy rainfall, cloud burst, GLOF, landslides, Slope failure, deforestation, drainage congestion due to urbanization. The Geospatial technique has been used to find out the relief, slope distribution and landslide hazard zonation and secondary data is taken to carry the analysis work. Primary data from each hotspot has been collected through a questionnaire survey and a Participatory Research Approach (PRA) and Livelihood options, Institutional participation in adaptation policy design and implementation, food security and Empowerment parameters like health and education (LIFE) approach. Present research highlights that most of the slope cutting and construction of roads are parallel to course of rivers, consequently slopes and roads have become highly vulnerable to landslides. Landslides vulnerability is increasing at an alarming rate due to unplanned and uncontrolled construction and other types of tourism based infrastructural development. Alaknanda river basin is an in-route gateway to millions of pilgrimages and religious as well as nature tourism movements. Hence, encroachments of the river side's and constructions of houses have increased the risk and vulnerability. Study also examines the possible ways to improve the living standards of the local community through ecotourism, sustainable development and disaster risk reduction techniques. This paper also provides various mitigation processes for the challenges faced in the Alaknanda river basin, Uttarakhand and attempts to formulate sustainable development strategy for the development of Alaknanda river basin.
\end{abstract}

\author{
Manuscript: \\ Received: Quadrennial Conferen- \\ ce of the International Geoscience \\ Education Organization \\ Accepted: 14/01/2018
}

Citation: Pandey B.W., Prasad A.S. 2018. Slope vulnerability, mass wasting and hydrological hazards in Himalaya: a case study of Alaknanda Basin, Uttarakhand. Terræ Didatica, 14(4):395-404. URL: http:// www.ige.unicamp.br/terraedidatica/.

Keywords: Anthropogenic Activity, Geo-hydrological hazards, Sustainable Development, Landslides Hazard Zonation, Disaster Risk Reduction

\section{Introduction}

Cloudburst triggered flash floods, Glacial Lake Outburst Flood (GLOF), debris-flow, mass movement, soil erosion and landslides are the major disasters in the Alaknanda river basin, Garhwal Himalaya, Uttarakhand. There are many instances in the recent past (2013) when these catastrophes caused heavy losses/damages to life, livelihood and properties. The Alaknanda river basin's landscape is very fragile and the human settlements are located along the perennial streams of rivers and on the unstable slopes. These perennial streams and big rivers are highly violent during monsoon period and whenever the water level of these streams rises; it causes heavy loss to property and lives through the destruction of human settlements located along the course. The tourists and the local people/communities do not adopt proper agricultural practices of hillside farming (Pandey, 2010). Moreover, large scale construction of the roads in this fragile region has made land resource more vulnerable. Landside and soil erosion have become common feature in this river basin (Pandey 2002). Soil erosion, landslide and fragile situations of the region do not provide ample opportunities to farmers to stay in the agricultural sector. Hence, they are forced to leave to the better opportunities in cities of northern region of India (Bandooni 2004).

The Himalaya is considered to be the youngest mountain and is tectonically active, hence geologically vulnerable to hazards and disasters (Pandey 
\& Prasad 2016).In the Himalaya region, the nature of land varies widely ranging from gentle plains to very steep slopes, deep valleys, gorges, terraces, saddles, laccustrine deposited, lakes, rivers and very high snow-clad peaks (Kumar \& Negi 2017). The historical data of rainfall, cloudburst and consequent flash flood, landslides and landslips depict that each year heavy rainfall occur during monsoon period and the entire region is affected from the same (District Disaster Management Authority 2013). With the process of development, in terms of construction of roads and dams using highly explosive measures, the rocks become more fragile and after heavy rainfall and cloud burst, the loosened materials of the rocks wash away and finally the process of landslides and mass movement take place. In order to describe the frequency and intensity of the hazards in the basin, it is observed that landslides are more devastating, intense and frequent. Cloudbursts followed by landslides are more prominent in the valley. A number of landslides and landslips take place during monsoon. It is more prone in those areas where hill slopes are being cut for road construction and proper drainage facilities do not exist. Due to this, soil flows along with the rivers and causes siltation/ sedimentation in the lower reaches which cause flood. Soil erosion and landslide are directly proportional to extent and magnitude of rainfall and flood. Whenever soil erosion has increased, average annual flooded area has also increased (Singh et al. 2014, Sati 2013). Monsoon rain is quite heavy and intense and maximum rainfall occur during June to September, which leads to slope failure, mass movement, soil erosion landslide, flash flood and debris-flow. Every year during the monsoon, heavy loss of lives and damage to property is recorded. The people of the region have well adapted to these situations and they have their own ways to adapt the climaterelated incidences through local techniques. Rainfall data vary from one season to another and from year to year. The basic pattern of climate is governed by summer and winter mon- soon systems of India. The maximum rainfall is observed in monsoon months due to south-west monsoon which normally strikes the Garhwal Himalayas towards the end of June and withdraws from the region at the end of September. During disaster and post-disaster high vulnerable issues such as damage to houses/properties, drinking water, electricity, emotional well-being, health well-beingis identified.

\section{Study Area}

The Alaknanda basin extends between $30^{\circ} 0$ ' N to $31^{\circ} 0^{\prime} \mathrm{N}$ and $78^{\circ} 45^{\prime} \mathrm{E}$ to $80^{\circ} 0^{\prime} \mathrm{E}$ covering an area about $10882 \mathrm{Km}^{2}$, of the eastern part of Garhwal Himalaya (Fig. 1).

Alaknanda river basin in Uttarakhand covers development blocks of Bageshwar, Chamoli, Rudraprayag, Tehri, Pauri Garhwal and Pithoragarh districts. Alaknanda river meets Bhagirathi river at Devprayag and forms common stream of Ganga river. The land under agriculture is $644.22 \mathrm{~km}^{2}$ which is 5.9 per cent of the total geographical area while only $64.8 \mathrm{Km}^{2}$ (0.6 per cent) land is under the horticultural crops (Pal, 1986). The drainage pattern is of sub-parallel and dendrite type, which is mainly structurally controlled.Altitudinal variation from $442 \mathrm{~m}$ to $7,816 \mathrm{~m}$ in the Alaknanda catchment has given rise to a variety of climates ranging from subtropical, temperate, sub-alpine to alpine.Rainfall varies widely in the catchment. Its quantity to a large extent depends on the location of the place to the windward and leeward side of the high ridges (Varun 2006). The entire catchment basin is influenced by

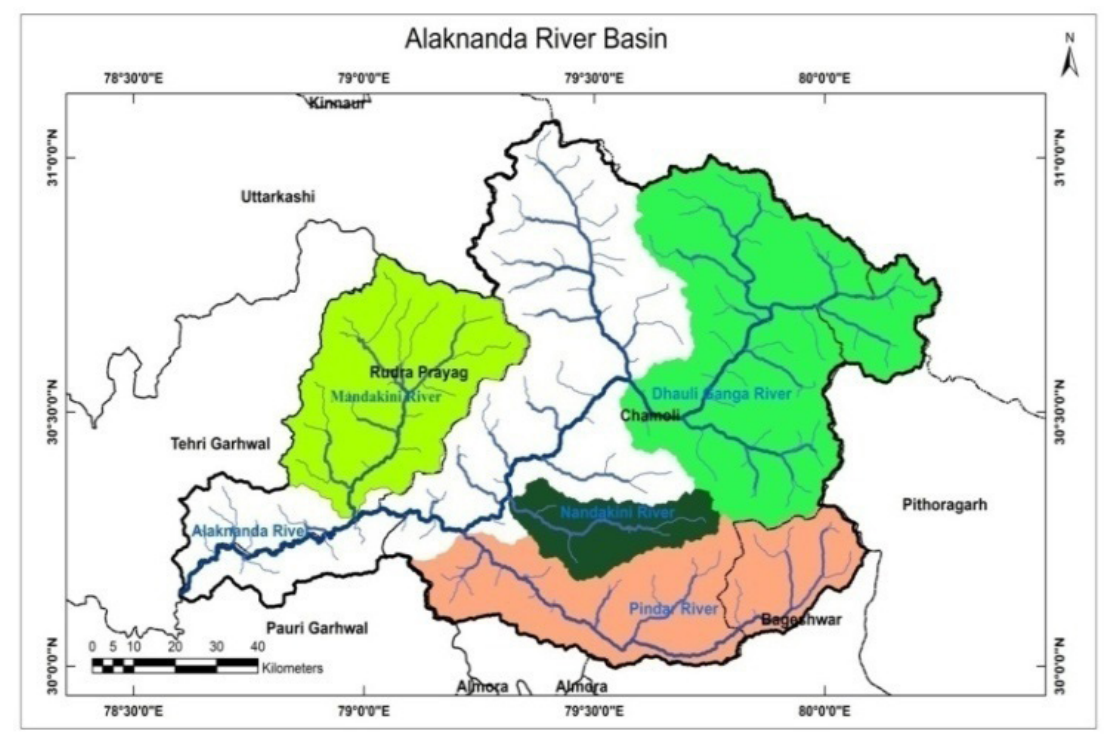

Figure 1. Alaknanda River Basin, Uttarakhand. Source: Landsat TM 
the south-west monsoon as 70 to 80 per cent of the total rainfalls occur during this period.

\section{Research Methodology}

Study is based on both the primary and as well as the secondary data sources. Primary data has been collected through field survey. Both qualitative and quantitative methods have been used in the study. The perceptions of the local community regarding different aspects of sustainability and hazard occurrences and management have been gathered through a pre-structured questionnaire. Informal interviews and discussions with local people and officials provided information about the locations of prior events and did surveys of historical documents. The analysis is based on maps from Survey of India, and satellite imageries. Various thematic maps pertaining to drainage, geological structure and land use/land cover were generated with the help of ArcGIS 10.3 and ERDAS 9.3 software. Quantitatively, formal interviews and discussions with tour operators and travel agents and contingent valuation methods (survey-based interviews with domestic and international tourists) were employed during the fieldwork period. First, 300 household survey have been conducted at 30 villages to obtain information on socioeconomic conditions. A structured questionnaire has been prepared to record relevant information. The households have been selected on the basis of Stratified Random Sampling (SRS). Second, a block level survey has conducted covering 13 developmental blocks to study farming system and level of livelihood. An inventory sheet has been prepared to record information such as types and extent of diversifying livelihood options in the selected areas and collect additional information about the possibilities of enhancing the options of livelihood rather than the prevailing traditional system of agriculture. The interview questions have been grouped into 3 sets such as (1) sustainability of existing farming system (2) responses towards the adoption of diverse crops (3) reliability of diverse livelihood options. The analysis is based on maps from Survey of India, and satellite imageries.

The qualitative methods involves group discussions and interviews with local elder people and patrons, group of local households, local authorities and semi-governmental officers, NGO/development agencies staffs and participant observation.
Quantitatively, formal interviews with potential tour operators and travel agents and contingent valuation methods (survey-based interviews with domestic and international tourists). The questionnaire includes questions related to local inhabitants and tourists perception about Natural hazards and livelihood options in the Alaknanda river basin. The study is based on the primary and secondary data. Both data were utilised for analysis the livelihood vulnerability and adaptation issues for the disaster risk reduction and livelihood security. The primary and secondary data were utilized for analysis of livelihood security, vulnerability and adaptation issues for the disaster risk reduction. Perceptions of local community regarding different aspects of sustainability, hazard occurrences and its management were recorded through reconnaissance survey and semi-structured questionnaire. The simple random sampling technique was used for the primary survey.Likert scale was employed for analysing the peoples' perception regarding the origin, trend, frequency, magnitude of hazards and the techniques to control the hazards in Alaknanda river basin. It was also designed to determine and identify the opinion of the subject. In Likert scale, categories have been assigned into 5 responses. Usually, the most negative responses are numerated into a given numerical lowest values of 1 , whilst the most positive response has a numerical highest value of 5 such as strongly agree (5), agree (4), uncertain (3), disagree (2), strongly disagree (1) (Likert 1932).

\section{Results and Discussions}

\section{Perceptions about Responsible Causes of Hazards in Alaknanda River Basin}

Research highlights that most of the landslides have occurred on the human-modified landscape and complex geo-dynamics phenomenon. It is directly related to slope cutting and excavation for various development works. However, to stabilise the landslide site to restrict progressive failure both structural and non-structural approaches are required. There should be strict regulation for felling of trees and afforestation should be encouraged. Local level policy makers are well aware of the issues related to adverse impact of climatic change, but their primary concern is about the immediate socio-economic issues of local relevance.Deforesta- 
tion, slope cutting and heavy rainfall are key driving factors causing several hazards particularly soil erosion, landslides and rock fall in the Alaknanda river basin (Table 1). It is triggered by both anthropogenic and natural causes. Slope cutting due to road construction, deforestation and lack of drainage technique are the basic factors identified for the origin of rockfall. Overgrazing, heavy rainfall and tourism were identified as other responsible factors for rockfall hazards, soil erosionand associated factors.About 72 out of 100 respondents recognized the faulty agricultural practices as a tool for soil erosion hazard (Tab. 1). This indicates that the valley is prone to cloudbursts (Ministry of Disaster Management and Mitigation Centre, Dehradun, Uttarakhand 2016).

It is directly related to local geo-environmental situations, slope cutting and excavation for the various development works. However, to stabilize the landslide sites and to restrict progressive failures, both structural and non-structural approaches are required. There should be strict regulations against felling of trees and afforestation and reforestation should be encouraged.

\section{Natural Hazards Assessment on Geomorphic and Geologic Parameters}

\section{Slope Cutting for Construction}

Unplanned and haphazard construction is taking place all along the valley without taking into consideration the geolithological structure, leading to large-scale disruption. Slope cutting takes place for the construction of roads and hotels, buildings and other tourism-related facilities. The slope cutting directly affects the runoff, soil formation and soil erosion. In the Alaknanda river basin, very gentle to the moderately sloping area is found in 2.5 per cent of total area. This type of land has slope less than 15 per cent and it is mainly situated along the river banks of Alaknanda, also Chamanpur, and Chandrabhaga river in the northwest, Mandakini and Dhauli Ganga river in the northern part. The slope ranging between 15 and 45 per cent is known as steep to very sloping and it occupies nearly 13 per cent area of Alaknanda river basin. Slope ranging 45 per cent occupies nearly 28 per cent area of the basin. One large continuous belt of this zone extends from north-western part (Ukhimath block) to the central (Desoli and Ghat block) part of the basin. Other main areas of this type are located in upper partAlaknanda and Dhauli Ganga sub-basin in the north (Joshimath block), and south-east (Kapkot and Deval blocks). The important features of this area are the steep slope, very shallow depth of the soils, rocky and barren land, less area under forest and very less area under cultivation. Slope ranging 45 per cent or more occupied area is more responsible for soil erosion, landslides and hydrological hazards (Sati 2014).

Hydrologic and geomorphic are two important indicators to determine the natural hazard events in Alaknanda river basin. Highly diversified surface topographic and geomorphic features describe the physiographiccharacteristics of Alaknanda basin. In the high-mountain glaciated areas ( $>4000$ meters above mean sea level, heavy rainfall and rapid

Table 1. Peoples' Perceptions Regarding Responsible Causes of Devastation (in Likert scale, 1-5)

\begin{tabular}{l|c|c|c|c|c|c}
\hline \multicolumn{1}{c|}{ Hazards/Causes } & Landslides & Floods & Avalanche & Cloudburst & Rock-fall & Soil Erosion \\
\hline Deforestation & 5 & 5 & 3 & 4 & 4 & 5 \\
\hline Slope cutting and construction of Roads & 5 & 0 & 1 & 0 & 4 & 5 \\
\hline Settlement (Haphazard Constructions) & 4 & 4 & 1 & 0 & 2 & 5 \\
\hline Improper Draining on slopes & 3 & 1 & 1 & 0 & 2 & 5 \\
\hline Overgrazing & 3 & 0 & 0 & 0 & 3 & 4 \\
\hline Steep Slopes & 3 & 1 & 4 & 0 & 3 & 3 \\
\hline Heavy Snowfall & 0 & 1 & 5 & 0 & 1 & 1 \\
\hline Glacial Lake Outburst & 0 & 3 & 1 & 0 & 1 & 2 \\
\hline Heavy Rainfall & 5 & 5 & 2 & 3 & 2 & 4 \\
\hline Changing Land Uses & 2 & 1 & 1 & 2 & 1 & 2 \\
\hline Tourism & 2 & 1 & 1 & 1 & 2 & 1 \\
\hline Faulty Agricultural Practices & 1 & 1 & 1 & 1 & 2 & 5 \\
\hline
\end{tabular}

Source: Based on Primary Survey 2016 


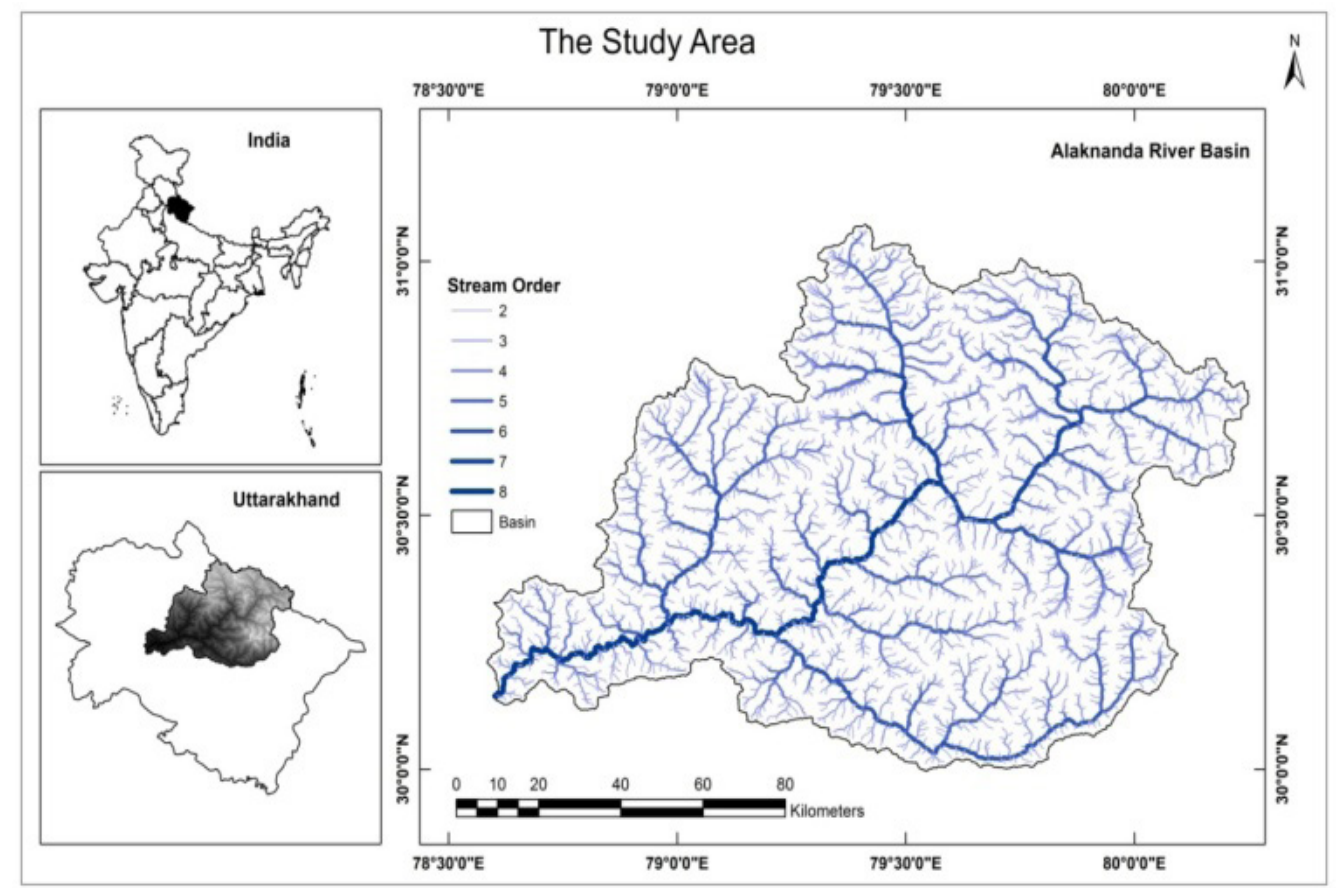

Figure 2. Drainage Density in the Alaknanda River Basin, Uttarakhand. Source: Extracted from Cartosat 1 DEM

melting of snow/ice have resulted in the formation and expansion of numerous moraine dammed lakes, creating a potential danger from dammed lake outburst floods to the human population and infrastructure (Bajracharya \& Mool 2009).

\section{Drainage Density and Landslide}

The landslide distribution in different drainage density classes is shown in Figure 2. The maximum number of landslides amounting to 115 (forming 35.49 per cent of the total number of natural hazards) is restricted to Class-3 drainage density (2-4 $\mathrm{km} / \mathrm{km} 2$ ) while the minimum number of landslides is confined to Class-1 drainage density $(<$ $1 \mathrm{~km} / \mathrm{km} 2$ ).

Tributary of river basin varies due to differences in slope and topographic conditions. Changes of stream length ratio from one order to another order have indicated their late youth stage of geomorphic development .

\section{Relief}

The distribution of natural hazards and landslide in different absolute relief classes has been shown in Figure 3. A maximum number of landslides to the extent of 110 forming 40.70 per cent of the total landslides is restricted to $(3500-5000$ $\mathrm{m})$ while only 10 landslide falls in Class $-1(<1500$ $\mathrm{m}$ ) which forms 3.70 per cent of the total number of natural hazards.

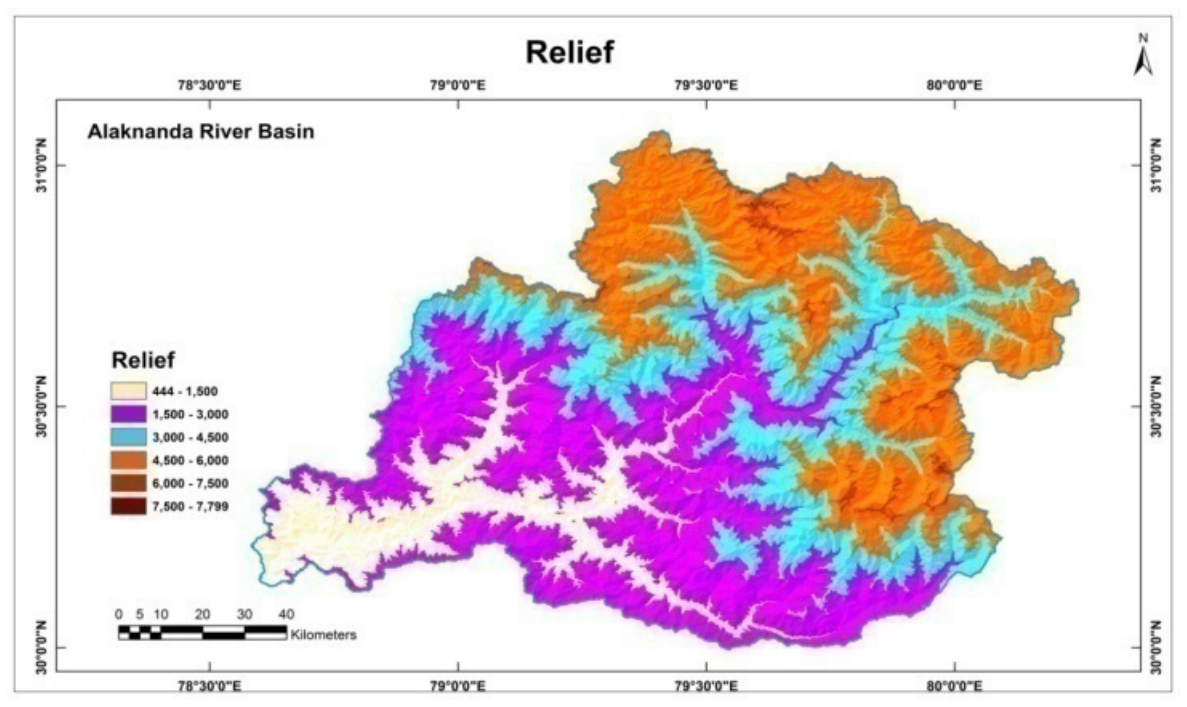

Figure 3. Relief Variations in Alaknanda River Basin, Uttarakhand. Source: Extracted from Cartosat 1 DEM 
Lower and lower-middle valley are found between 444 to 1500 meters altitude mainly in the southern part of the basin and it occupies about 12 per cent of area covering parts of Devprayag, Kirtinagar, Kot, Pauri, Khirsu, Jakholi, Augustyamuni, Karanprayag, and Narayan blocks. Most of the blocks are in the south-west parts (Pauri, Devprayag, Nandaprayag to Joshimath in the middle Alaknanda river basin (Dasoli block), Nandakini sub-basin, Chandrapuri to Gaurikund in Mandakini sub-basin (Augustyamuni and Ukhimath block), (Fig. 4).Upper middle valley and mountains are found in Ukhimath, Dasoli, Ghat, Joshimath, and Kapkot blocks and are about 16 per cent area of the basin. The altitude of this basin is 3000-4500 meters. The main valley is along Mandakini, Kaliganga river in north-west, along Pindar and Kaphni rivers in south-east and lower part of Girthi Ganga of Dhauli Ganga sub-basin. This region is also vulnerable to natural hazards (Bandooni 2004). Northern and Eastern part of Alaknanda basin is the belt of the Greater and Zanskar Himalaya where altitude of the mountain is more than 4500 meters from the mean sea level. It occupies more than 50 per cent area of the basin, covering part of the Ujhimath, Joshimath, Munisari, DevalGhat and Kapkot blocks.

The main characteristics of this zone are more vulnerable to natural hazards, permafrost cover of snow, and less population and vegetable cover (Fig. 3).

\section{Slope Distribution and Landslide}

The distribution of landslide and natural hazards under various slope classes show that the maximum number of landslides to the extent of 150 belongs to the slope Class-3 $\left(20^{\circ}-30^{\circ}\right)$ forming almost 59 per cent of the total number of natural hazards (Flash Flood, landslide, soil erosion, cloudburst and Glacial Lake Outburst

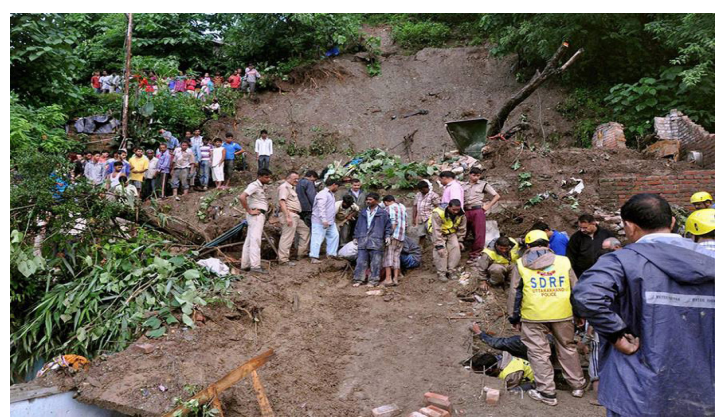

Figure 4. Landslide and Soil Erosion in Rudraprayag, Uttarakhand. Source: Primary Survey, 2016

Flood (GLOF). The area having $15-25^{\circ}$ slopes is the zone of gently-moderately to steep slopes. It occupied nearly 12 per cent area of the basin and is found maximum in the south-west (Devprayag, Kirtinagar, Pauri and Khirsu blocks) and Northwest (Jakholi block), south-east (Deval and Kapkot block) and northern part (Dasoli and Joshimath blocks) of the basin (Fig. 5).The slope ranging between 25 to 45 per cent is known as steep to very steep sloping zone and it occupied 40 per cent area of the Alaknanda river basin.

The main features of the area are steep slopes, very shallow depth of the soils, rocky and barren lands, less area under forest and very less area under cultivation (Table 2).

Other two narrow belts are located in the southern block border (Khirsu, Gairsain, and Tharali blocks) and the south-western (Kirtinagar, and Augustyamuni block) part of the basin. One large continuous belts of this zone extend from north-western part (Ukhimath block) to the

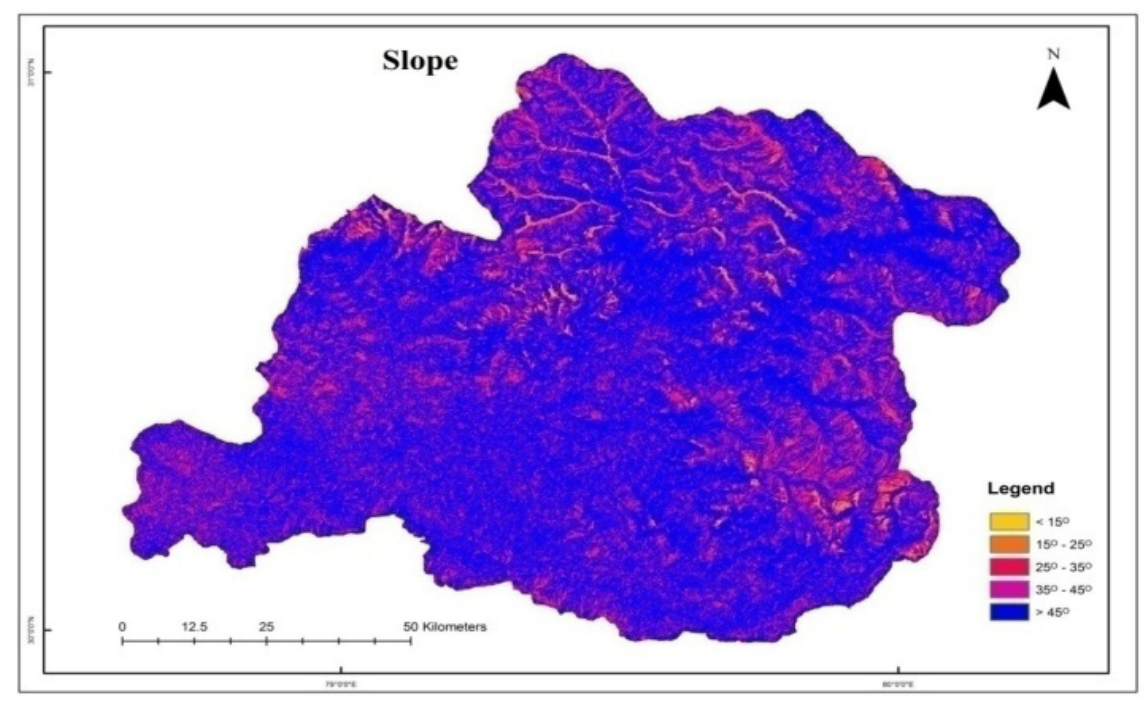

Figure 5: Slope Distribution, Alaknanda River Basin, Uttarakhand Source: Extracted from Cartosat 1 DEM

\begin{tabular}{c|c|c|c|c|c}
\hline (C) Terrae Didat. & Campinas, SP & v.14 & n.4 & p. 395-404 & out./dez. 2018 \\
\hline
\end{tabular}


Table 2. Natural Hazards Assessment on the Physiographic Features

\begin{tabular}{c|c|c|c|c|c|c|c|c}
\hline & \multicolumn{2}{|c|}{ Slope } & \multicolumn{2}{c|}{ Absolute Relief } & \multicolumn{2}{c|}{ Drainage Density } & \multicolumn{2}{c}{ Land use } \\
\hline & Classes & Events & Classes & Events & Classes & Events & Classes & Events \\
\hline 1. & $<15$ & 0 & $<1500$ & 10 & $<1$ & 15 & Mixed Open Forest & 95 \\
\hline 2. & $15-25$ & 10 & $1500-3000$ & 40 & $1-2$ & 48 & Dense Forest & 34 \\
\hline 3. & $25-35$ & 150 & $3000-4500$ & 70 & $2-4$ & 115 & Agriculture Land & 53 \\
\hline 4. & $35-45$ & 59 & $4500-6000$ & 110 & $4-6$ & 95 & Barren Land & 61 \\
\hline 5. & $>45$ & 35 & $>6000$ & 42 & $>6$ & 51 & Settlement & 110 \\
\hline Total & & 254 & & 272 & & 324 & & 353 \\
\hline
\end{tabular}

Source: Field Survey and Remote Sensing Data, 2013-2016

central (Dasloi and Ghat block) part of the basin. Other main areas under this sloping region are Upper Alaknanda and Dhauli Ganga sub-basin in the north (Joshimath block), South-east (Kapkot and Deval blocks) and south central (Karanprayag block) part of the basin (Fig. 6).

\section{Soil Erosion and Its Impact on Hydrological Hazards}

Soil erosion and its impact on mass-wasting and hydrological hazards (such as a flash flood) occurring in Alaknanda river basin are the results of slope length and steepness with rainfall and the deformed lithology. It is expected that a high altitude mountainous region would be eroded more rapidly than low elevation area. The rate of sediment weathering by physical and chemical processes is mostly determined by factors such as climate, bedrock, time, proximity to water, and human influences (Prasad and Pandey, 2017).
From 14 to 17 June 2013, Uttarakhand and the adjoining area experienced heavy rainfall, which was about 375 per cent more than the benchmark rainfall during a normal monsoon. This caused the melting of Chorabari Glacier at the height of 3,800 meters, and the eruption of the Mandakini river which led to heavy floods near Gobindghat, Kedarnath and Rudraprayag district, Uttarakhand and adjacent areas.

\subsection{Vulnerability and Adaptation Assessment for the NDH (Near the District Headquarter) and ADH (Away District Headquarter)}

The major components (Socio-Demographic Profile, Social Network, Health, Food, Water, natural capital, Natural Disaster, represents the subcomponents, which makes up each major component, and $\mathrm{n}$ is the number of sub-components in each component. The percentage of households reporting in their community was set at a mini-

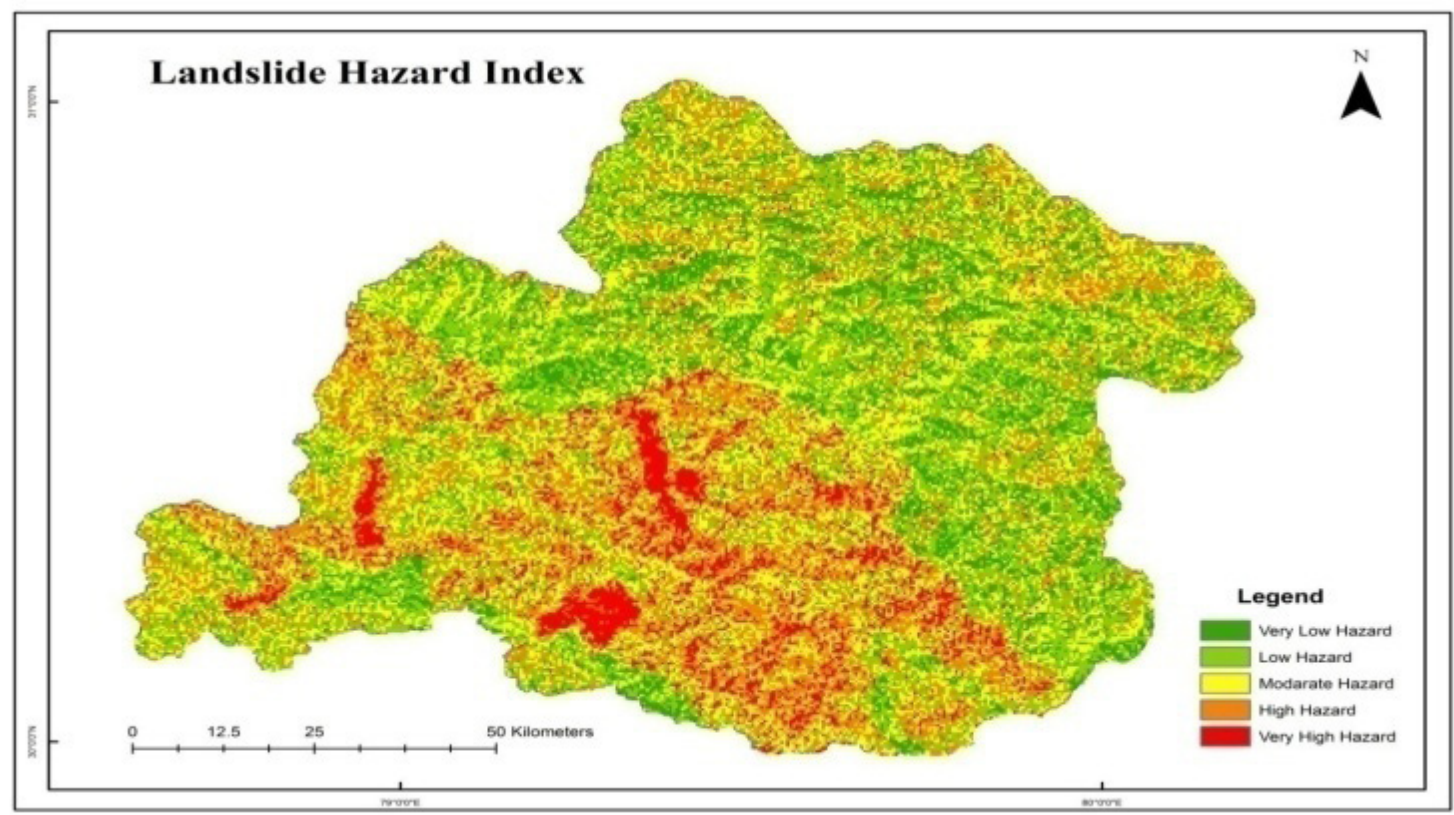

Figure: 6: Landslide Hazards Zonation in Alaknanda River Basin. - Source: Extracted From Satellite Image and Data Cartosat 1 DEM

\begin{tabular}{c|c|c|c|c|c}
\hline (C) Terrae Didat. & Campinas, SP & v.14 & n.4 & p. 395-404 & out./dez. 2018 \\
\hline
\end{tabular}


mum of 0 (High) and a maximum of 1 (Lowest) of a vulnerability index (Table 3 ).

Vulnerability index focuses on quantifying the strength of current livelihood including the dependence of natural resources and available infrastructures besides the prevailing local adaptive capability of communities. The vulnerability index has been acted as an instrument and developed to provide an informed decision for the policy makers, and development organisations at the spatial scale. The result of data analysis for the major components and sub-components comprising the livelihood vulnerability index developed for the NDH (Near the district headquarter) and ADH (Away District Headquarter) into eight sections such as socio-demographic profile, livelihood strategies, social network, natural capital, health, food, water, and natural disaster.

The vulnerability of NDH and ADH village's households differs because of differences in the households' sensitivity, adaptive capacity and exposure to natural disaster, which further reflected in their disaster recovery strategies such as disaster risk reduction. The high response for the natural disaster by $\mathrm{ADH}$ village's community is due to poor infrastructure and facility, support from external resources besides high dependency on natural resources.

The study highlights the difference in the socio-demographic index of the NDH (0.46) and $\mathrm{ADH}$ (0.55). ADH village's households are more vulnerable than NDH village's households. The livelihood strategies of ADH village's households are less diversified than NDH villages. The NDH households have more opportunity for adjustment within the framing system due to their traditional/ local knowledge about the climate change responses and government policy. This is very important for disaster risk reduction. The NDH village's households have better accessibility in terms of facilities and livelihood options than ADH household, thus, opted for crop variety change and the introduction of new crops. The social network status is similar (NDH-0.80 and ADH-0.79) in both the regions. This shows that ADH and NDH village's households are interdependent and sought co-operation among themselves. A large number of households reported having a strong social network in $\mathrm{ADH}$ villages. Families in $\mathrm{ADH}$ village reported less difficulty in acquiring adequate food and seed because of sufficient food grain production and social network within the village community.

In NDH village's households has reported the good health facility as a result of better livelihood options, government and private health facilities. $\mathrm{ADH}$ village's large numbers of households do not go for treatment in government and private hospitals and not have access to proper facilities for child delivery and immunization. In such households, even toilet facilities are unavailable in their houses. The highest number of households to report death or injury has reported in $\mathrm{ADH}$ villages. The high level of stress due to climate is noted in ADH (0.96), probably due to their high dependency on natural resources. The households of NDH village (0.68) reported the occurrence of more new diseases than the $\mathrm{ADH}(0.45)$, probably due to better communication and awareness about health hazards and health facility.

This paper identifies the NDH and ADH village's household vulnerability level, which may be helpful in formulating the policy for sustain-

Table 3. Index Dimension of Vulnerability NDH and ADH Village's Households

\begin{tabular}{c|c|c|c}
\hline $\begin{array}{l}\text { Vulnerability } \\
\text { Components }\end{array}$ & Major Components & $\begin{array}{c}\text { Vulnerability } \\
\text { Components NDH }\end{array}$ & $\begin{array}{c}\text { Vulnerability } \\
\text { Components ADH }\end{array}$ \\
\hline $\begin{array}{c}\text { Adaptive } \\
\text { Capacity }\end{array}$ & $\begin{array}{c}\text { 1. Socio-Demographic Profile } \\
\text { 2. Livelihood Strategies } \\
\text { 3. Social Network } \\
\text { 4. Natural Capital }\end{array}$ & $\mathbf{0 . 6 4}$ & $\mathbf{0 . 7 5}$ \\
\hline Sensitivity & $\begin{array}{c}\text { 1.Health } \\
\text { 2.Food } \\
\text { 3. Water }\end{array}$ & $\mathbf{0 . 4 3}$ & $\mathbf{0 . 6 6}$ \\
\hline Exposure & $\begin{array}{c}\text { 1.Natural Disaster, Warning and } \\
\text { 2. Impact Climatic Variability }\end{array}$ & $\mathbf{0 . 2 9}$ & $\mathbf{0 . 4 4}$
\end{tabular}

Source: Based on primary Survey, 2013-2016 
able development. To reduce the sensitivity of the households in the village, this, in turn, may help them to be more efficient in overcoming the shock caused by the disaster and re-establishing their livelihood. NDH and ADH village's household's vulnerability level, which may be helpful in formulating the policy for sustainable development. To reduce the sensitivity of the households in the village, this, in turn, may help them to be more efficient in overcoming the shock caused by the disaster and re-establishing their livelihood. Strategy for Hill Districts Infrastructure development is a common development agenda to facilitate development in the hill districts of Alaknanda river basin, Uttarakhand.

\section{Conclusion}

Land and agricultural resources of Alaknanda basin face many impediments in the way of development. All the impediments can be classified into three categories i.e., Physical, socio-institutional and techno-economic. Main physical impediments are altitude, slope, landslides, avalanches and soil erosion, while main socio-institutional impediments are outmigration, the size of land holdings, and fragmentation of holdings, poverty and lack of infrastructure. Main techno-economic impediments are a lack of irrigation facilities, lesser use of modern agriculture implements and low technical knowledge. Due to the construction of settlements along the streams and major rivers, Uttarakhand calamity turned into the disaster. The risk level and mapping of different kinds of hazards have been analysed with the help of peoples' perceptions and their attitudes. The suggestions based on suitability with optimum applicability to improve the environmental sustainability and livelihood security in the valley have been elaborated with suitable examples. Land use control has much in common with flood plain management; it should also be implemented in conjunction with a technical study on flash flood hazard mapping. Land use regulation is designed to reduce danger to life, property, and development when flash floods occur. The following elements should be addressed while implementing land use control in a watershed. Many of the elements mentioned here are directly related to planning and policy makers, although flash flood managers should also have a good understanding of these issues.

Some major fault zones in Alaknanda river basin are Rawanganga fault, Madhyamaheshwar fault, Mandakini fault, Godwanala fault and Kaldungnala fault due to which a number of landslides occur. It has been indicated that a maximum frequency of landslides occurs along Madhyamehashwar, Godwanala and Rawanganga faults. Such areas must be taken into consideration before any construction. Application of integrated and coordinated approach is the need of the hour to reduce vulnerabilities in Alaknanda valley. All the stakeholders including local community, government and non-governmental organisations, scientific community and planners should work together in a coordinated manner for sustainable future of mountain areas. Science-policy interface based on credible, salient, legitimate knowledge can lead to good planning in the context of climate change and mountain specificities.

\section{Acknowledgement:}

Authors are thankful to Research Council, University of Delhi for Research and Development Grant Project, 2015-2016.

\section{References}

Bajracharya S.R., Mool P. 2009. Glaciers, Glacial Lakes and Glacial Lake Outburst Floods in the Mount Everest region, Nepal. Annals of Glaciology, 50(53):81-86.

Bandooni S.K. 2004. Land Resources Management and Development in Hill Areas. New Delhi, Research Press India.

Kumar A., Negi M.S. 2017. Assessment of land capability and suitability classification for agriculture using geospatial techniques in Rudraprayag District (Garhwal Himalaya). In: Sati V.P., Lalmalsawmzauva K.C. eds. 2017. Natural Resources Management for Sustainable Development and Rural Livelihoods. New Delhi, Today and Tomorrow's Printers and Publishers. v. 2, p. 443-463.

Likert R. 1932. A Technique for the Measurement of Attitudes. Archives of Psychology, 140:1-55.

Ministry of Disaster Management and Mitigation Centre, 2016. Report of Disaster, Dehradun, Uttarakhand.

Pal S.K. 1986. Geomorphology of River Terraces along Alaknanda Valley, Garhwal Himalaya. Delhi, B.R. Publ. Co.

Pandey B.W.. Prasad A.S. 2016. Land Use Pattern and Hazards Risk Assessment in Kullu Valley along the Beas River in Western Himalaya. Beijing, China, Journal of Land Use and Water Management, Special Issues - IGC 2016, 16(1-2):01-18.

Pandey B.W. 2010. Hazard Ecology: Approaches and Techniques (ed) Mittal Publication, New Delhi.

Pandey B.W. 2002. Geoenvironmental Hazards in Himalaya: Assessment and Mapping. New Delhi: Mittal Publ.

\begin{tabular}{|c|c|c|c|c|c|}
\hline (C) Terrae Didat. & Campinas, SP & v.14 & n.4 & p. 395-404 $/$ dez. 2018 \\
\hline
\end{tabular}


Prasad A.S., Pandey B.W. 2017, Climate Change, Land Use and Land Cover Change Detection and Its Impact on Hydrological Hazards and Sustainable Developments: A case Study of Alaknanda River Basin, Uttarakhand, India. Riscurisi Catastrofe Journal, An XVI, 20:55-68.

Sati V. P. 2013. Tourism Practices and Approaches for its Development in Uttarakhand, Himalaya, India. Journal of Tourism Challenges and Trends, Innovation in Tourism, IV(1).

Sati V.P. 2014. Landscape Vulnerability and Rehabilitation Issues: a Study of Hydropower Projects in the Garhwal region, Himalaya. Natural Hazards replaced by Natural Hazards: Journal of the International Society for the Prevention and Mitigation of Natural Hazards. 75(3):2265-2278. DOI: 10.1007/ s11069-014)-1430-y.
Sati V.P. 2014. Towards Sustainable Livelihoods and Ecosystems in Mountain Regions, Environmental Science. Springer Intern. Publ. DOI: 10.1007/978-3-31903533-8.

Singh R.B., Pandey B.W., Prasad A.S. 2014. Extent and Magnitude of Flood due to Soil Erosion in Lower Brahmaputra River Basin, Assam. Annals of the National Association of the Geographers India (NAGI).

Singh P., Haritashya U.K., Kumar N., Singh Y., 2006, Hydrological Characteristics of the Gangotri Glacier, Central Himalayas. India. J. Hydrology, 327:55-67.

Varun J. 2006. Extreme Rainfall Events and Associated Natural Hazards in Alaknanda Valley, Indian Himalayan Region. Journal of Mountain Science, 3(3):228-236. 